Kajian Jurnalisme

Volume 04 Nomor 02 Tahun 2021

DOI: $10.24198 / j k j . v 4 i 2.27156$

\title{
Penerapan Pagar Api pada Female Daily Network
}

\author{
Cristine Manik, Henny Sri Mulyani dan Ika Merdekawati Kusmayadi \\ Bisnis Indonesia \\ cristine.evifania@gmail.com
}

\begin{abstract}
This study aims to find out how the advertorial production process on lifestyle media Female Daily Network's website and YouTube, what policies are applied to regulate advertising, and how the firewall principle is applied to advertorial content. The background of this research is the massive growth of internet advertising in Indonesia. This study used the qualitative method with a case study by Robert E. Stake's approach. Researchers used an intrinsic case study because there is an apparent uniqueness about how the Female Daily Network produces advertisements. This study's data is collected through observation, interviews, qualitative documents, audio-visual material, literature studies, and online data search. The results showed that the Female Daily Network produces advertorials in two stages, named sales process and production process (running campaign). Female Daily Network does not have strict provisions in accepting advertising cooperation, so they have to negotiate in advance with potential advertisers. The editorial team is responsible for editorial and advertorial writing. Negotiations with advertisers affect journalism activities to the extent of biasing the boundaries between advertorial and editorials in Female Daily Network, even though the firewall principle began to be applied. The researcher suggests to have firm firewall boundaries between editorial and advertorial; the Female Daily Network creates particular segments for both. By having a video for the advertorials and a specific column for the articles, separating human resources workflow, and setting advertising policies that are strict with advertisers.
\end{abstract}

Keywords: journalism; female daily network; advertorial; firewall; lifestyle media

\begin{abstract}
Abstrak
Penelitian ini bertujuan untuk mengetahui bagaimana proses produksi advertorial pada website dan YouTube media gaya hidup Female Daily Network, apa kebijakan yang diterapkan untuk mengatur iklan, dan bagaimana prinsip pagar api diterapkan pada konten advertorial. Penelitian ini dilatarbelakangi oleh masifnya pertumbuhan iklan internet di Indonesia. Penelitian ini menggunakan metode kualitatif dengan pendekatan studi kasus intrinsik Robert E. Stake. Peneliti menggunakan studi kasus intrinsik karena terdapat keunikan yang jelas mengenai cara Female Daily Network memproduksi iklan. Data dikumpulkan melalui observasi, wawancara, dokumen kualitatif, materi audiovisual, studi literatur, dan penelusuran data online. Hasil penelitian menunjukkan bahwa Female Daily Network memproduksi advertorial dalam dua tahap, yaitu proses penjualan dan proses produksi (running campaign). Female Daily Network tidak memiliki ketentuan yang ketat dalam penerimaan kerja sama iklan sehingga harus selalu melakukan negosiasi terlebih dahulu dengan calon pengiklan. Tim redaksi bertugas untuk menulis editorial dan advertorial. Negosiasi dengan pengiklan mempengaruhi aktivitas jurnalistik hingga menimbulkan bias batasan antara advertorial dan editorial di Female Daily Network, meskipun prinsip pagar api mulai diterapkan. Peneliti menyarankan agar Female Daily Network memperjelas batasan pagar api antara editorial dan advertorial dengan cara membuat segmen khusus untuk video advertorial dan kanal khusus untuk artikel; memisahkan alur kerja sumber daya manusianya; dan mengatur kebijakan mengiklan yang tegas terhadap pengiklan.
\end{abstract}

Kata kunci: jurnalisme; Female Daily Network; advertorial; pagar api; media gaya hidup

Korespondensi: Cristine Manik, S.I.Kom., Bisnis Indonesia Perwakilan Medan, Komplek Istana Bisnis Center, Jl. Brigjend Katamso No. 4, Medan, Sumatera Utara 20212,

Email: cristine.evifania@gmail.com

Menyerahkan: Mei 2020, Diterima: Januari 2021, Terbit: Januari 2021

ISSN: 2549-0559 (cetak), ISSN: 2549-1946 (online), Website: http://jurnal.unpad.ac.id/kajian-jurnalisme 
178 | Kajian Jurnalisme

Volume 04 Nomor 02 Tahun 2021

DOI: $10.24198 / \mathrm{jkj} . \mathrm{v} 4 \mathrm{i} 2.27156$

\section{PENDAHULUAN}

Iklan memiliki posisi yang penting terhadap keberlangsungan bisnis media massa, mengingat media massa memiliki dua wajah, sebagai institusi bisnis dan institusi sosial. Sebagai institusi bisnis, media menjalankan operasi untuk kepentingan sendiri (Alfarabi, 2010) salah satunya dengan menerima iklan. Di saat media cetak mengalami penurunan pengiklan, iklan di media digital terus bertambah. Tren baru ini juga sangat dirasakan oleh media gaya hidup yang memiliki pasar tersegmentasi. Salah satu media gaya hidup berbasis digital yang merasakan dampak iklan digital adalah Female Daily Network (FDN).

Pertumbuhan pesat internet membawa tren baru pada dunia periklanan. Sejak tahun 2016, total belanja iklan internet mengalami peningkatan. Survei lembaga penelitian Nielsen melaporkan pertumbuhan belanja di Indonesia tahun 2016 memperlihatkan pergerakan positif dengan nilai pertumbuhan sebesar $18 \%$ (Nielsen, 2016). Data tersebut dikuatkan oleh prediksi yang dilaporkan lembaga firma PricewaterhouseCoopers $(\mathrm{PwC})$, yang menyatakan pertumbuhan iklan terbesar akan berada di internet dari porsi $13,1 \%$ menjadi $21.5 \%$ pada tahun 2021 jika dibandingkan dengan tahun 2016 (Nabila, 2017).

Pendekatan yang dilakukan FDN adalah dengan softselling untuk memunculkan kedekatan emosional terhadap produk yang diiklankan. Melalui pendekatan ini, pesan-pesan komersil disisipkan dalam bentuk tulisan di website femaledaily.com maupun audio visual pada channel YouTube FDN. Bentuk strategi marketing ini memproduksi artikel dan video berbentuk ulasan yang bertujuan mempromosikan suatu produk atau dikenal dengan advertorial. Namun, advertorial ini menjadi tidak sejalan dengan prinsip jurnalistik.

Pada umumnya, media gaya hidup memang dipenuhi iklan. Tidak ada batas yang jelas antara iklan dan karya jurnalistik. Batasan ini sering disebut dengan istilah pagar api (firewall). Harsono (2010) menuliskan media gaya hidup, terlebih majalah perempuan banyak yang dibiayai industri kecantikan. Iklan sering kali disamarkan seolah-olah dia adalah produk jurnalistik dengan menggunakan teknik jurnalistik (Sumadiria, 2014). Penelitian yang dilakukan oleh Lamalo (2013) menemukan bahwa jurnalis Manado Post dituntut untuk berperan ganda sebagai penawar iklan untuk membantu omset perusahaan. Hal ini dapat menimbulkan masalah jika tidak memiliki batasan yang tegas.

Mengutip dari Bill Kovach, Harsono menyatakan keberadaan pagar api wajib hukumnya di media massa. Lebih lanjut Harsono menjelaskan,

"Advertorial adalah gabungan dua kata: advertisement dan editorial. Pagar api (firewall) mengingatkan bahwa orang advertisement tak boleh ikut campur urusan editorial. Sebaliknya redaktur dan wartawan tidak usah ikut campur urusan iklan." (Harsono, 2010)

Konsep firewall yang memisahkan peran jurnalisme, iklan, dan public relation (PR) saat ini menjadi kabur (Nasrullah, 2020). Bias firewall antara iklan dan editorial bukan hanya terjadi di media lama seperti majalah, tetapi juga di media baru, salah satunya Female Daily Network (FDN). FDN merupakan media gaya hidup berbasis internet dengan informasi seputar kosmetik dan produk perawatan kulit.

Bias ini sangat jelas terlihat di video ulasan FDN yang dibagikan di channel YouTube FDN. Beberapa ulasan berbentuk video disponsori oleh produk kecantikan. Salah satu iklan yang disamarkan menjadi ulasan adalah video berjudul Rekomendasi Skincare Saat Puasa. Video ini diupload di YouTube pada 19 Mei 2019 (Ochell, 2019). Dalam video ini terdapat pengulas yang merupakan tim editorial (redaksi) FDN bernama Shella Sanjaya yang memberi ulasan mengenai produk perawatan kulit saat puasa. Yang menjadi masaah, salah satu produk bermerk Clinique merupakan sponsor video tersebut. Ulasan yang dijelaskan didominasi 
Volume 04 Nomor 02 Tahun 2021

DOI: $10.24198 /$ jkj.v4i2.27156

penjelasan tentang kelebihan produk Clinique tersebut. Pada bagian akhir, pengulas cenderung merekomendasikan produk Clinique untuk digunakan daripada produk lain. Padahal tujuan dari firewall yakni membangun objektivitas sebuah laporan berita dan mempertahankan etika jurnalistik (Nasrullah, 2020).

Di FDN yang membedakan antara produk sponsor dan opini resmi dari pihak redaksi (editorial) hanya terletak di description box. Terdapat keterangan 'thankyou (nama produk) for supporting our video' pada akhir kalimat untuk produk yang disponsori oleh brand-brand kecantikan. Namun, tidak ada segmen khusus yang disediakan FDN untuk video sponsor. Video yang berisi iklan ini menyebar hampir di seluruh segmen yang ada di YouTube FDN.

Tak hanya YouTube, ketiadaan batas antara produk iklan dan editorial juga terlihat pada website femaledaily.com. Terdapat kolom 'editorial' di mana penulis artikel merupakan tim editorial (tim redaksi) FDN. Di balik artikel yang ada pada kolom editorial, terdapat titipan sponsor berupa harga produk dan tempat pembelian produk. Salah satunya adalah artikel berjudul Somethinc: Serum Lokal Baru dengan Active Ingredients. Merujuk pada Nasrullah (2020), staf produksi berita mempunyai tanggung jawab dalam memproduksi kontennya dan sadar akan adanya tembok pemisah antara newsroom dan advertising, sehingga terdapat aturan yang ditegakkan, seperti tidak ada opini dari jurnalis dalam konten dan iklan pun secara jelas terpisah dari konten editorial.

FDN merupakan media baru yang pertumbuhan khalayaknya sangat pesat. Dari seluruh media baru yang memiliki konsep serupa dengan FDN, media ini memiliki audiens paling banyak. Berdasarkan catatan milik FDN, terdapat dua juta pengguna setiap bulan, sembilan juta pengunjung website, lebih dari 180.000 review di dalamnya, dan lebih dari 290 ribu member yang telah bergabung bersama FDN. Selain itu, media ini juga merupakan pelopor pertumbuhan platform kecantikan di Indonesia (Female Daily Network, 2018).

Tabel 1 Jumlah subscriber media gaya hidup yang menggunakan platform YouTube

\begin{tabular}{|c|l|r|r|l|}
\hline No & Nama Channel & \multicolumn{1}{c|}{ Subscriber } & Penayangan (kali) & Waktu Gabung \\
\hline 1 & $\begin{array}{l}\text { Female Daily } \\
\text { Network }\end{array}$ & 744.455 & 97.904 .255 & 8 Juni 2011 \\
\hline 2 & $\begin{array}{l}\text { Sociolla Beauty } \\
\text { Journal }\end{array}$ & 60.090 & 5.921 .057 & 3 Desember 2014 \\
\hline 3 & Fimela Media & 56.548 & 23.168 .023 & 25 Oktober 2010 \\
\hline 4 & Nova & 55.120 & 14.962 .692 & 1 Agustus 2013 \\
\hline 5 & Gadis Magazine & 24.764 & 12.633 .898 & 18 November 2009 \\
\hline 6 & Popbella & 38.827 & 297.756 & 29 Juli 2016 \\
\hline 7 & Channel Indonesia & 4.460 & 1.194 .764 & 29 Oktober 2014 \\
\hline 8 & Majalah Kartini & 130 & 91.336 & 11 April 2018 \\
\hline 9 & Kompas Lifestyle & & 14 Maret 2017 \\
\hline
\end{tabular}

(Sumber: Observasi Peneliti) 
180 | Kajian Jurnalisme

Volume 04 Nomor 02 Tahun 2021

DOI: $10.24198 / \mathrm{jkj} . \mathrm{v} 4 \mathrm{i} 2.27156$

Penelitian ini menjadi penting mengingat studi yang membahas antara batasan iklan dan hubungan jurnalisme di Indonesia masih amat minim. Iklan dan jurnalisme memandang khalayak secara berbeda. Jurnalisme memandang khalayak sebagai konsumen atas informasi dan maka dari itu jurnalisme bertanggung jawab untuk memberikan informasi yang menarik dna relevan, komprehensif dan proposional. Lain halnya iklan bertujuan untuk memasukkan konten komersial kepada khalayak (Baran, 2011). Pengiklan juga tidak segan untuk mengaburkan antara "berita" dan iklan (Basen, 2012). Basen menjelaskan bahwa saat ini, dengan tambahan bayaran, tidak sedikit iklan dapat dibuat dan ditempatkan pada surat kabar dengan menyamar sebagai berita, tanpa ada penjelasan yang memungkinkan pembaca untuk membedakan antara materi yang telah dibayarkan oleh pengiklan, dengan yang dihasilkan oleh jurnalis media tersebut.

Terdapat suatu fenomena pada media ini, yaitu terdapat bias antara editorial yang merupakan produk jurnalistik dengan iklan. Penelitian ini mengamati bagaimana penerapan firewall (pagar api) yang dilakukan oleh FDN. Lebih Jelasnya, penelitian ini mencari tahu bagaimana FDN memproduksi konten pada medianya, bagaimana aturan pembatasan iklan pada FDN, dan bagaimana ekonomi politik yang melatarbelakangi relasi antara pengiklan dengan produksi konten di media ini.

\section{METODE}

Peneliti menggunakan metode penelitian kualitatif. Penelitian kualitatif merupakan penelitian yang memanfaatkan wawancara terbuka untuk menelaah dan memahami sikap, pandangan, perasaan, dan perilaku individu atau sekelompok orang. Penelitian kualitatif didasarkan pada upaya membangun pandangan mereka yang diteliti rinci, dibentuk dengan kata-kata, gambaran holistik dan rumit (Moleong, 2017). Paradigma yang digunakan adalah paradigma kontruktivis. Di mana peneliti ingin mengonstruksi aktivitas produksi pada Female Daily Network dan menjelaskan penerapan pagar api yang ada dalam proses tersebut. Paradigma konstruktivis melihat bahwa ilmu sosial perlu untuk mengkaji meaningful social action. Max Weber melihat bahwa ada alasan dan motivasi personal dalam membentuk perasaan individu dan mendorongnya untuk melakukan perbuatan tertentu (Neumann, 2003).

Peneliti menggunakan metodologi penelitian studi kasus intrinsik Robert E. Stake. Studi kasus adalah salah satu metode penelitian ilmu-ilmu sosial. Secara umum, studi kasus merupakan strategi yang lebih cocok bila pokok pertanyaan suatu penelitian berkenaan dengan how dan why, bila peneliti hanya memiliki sedikit peluang untuk mengontrol pristiwa-peristiwa yang akan diselidiki dan bilamana fokus penelitiannya terletak pada fenomena kontemporer dalam konteks kehidupan nyata (Yin, 2014).

Stake mengidentifikasi studi kasus ke dalam tiga tipe. Ketiga tipe tersebut adalah studi kasus intrinsik, studi kasus instrumental, dan studi kasus kolektif. Menurut Stake (2005) tujuan kategorisasi yang dilakukannya bukanlah taksonomik, melainkan untuk menekankan variasi terkait dan orientasi metodologi terhadap kasus.

Penelitian ini menggunakan metode studi kasus sebab ketiga identifikasi masalah penelitian ini untuk menjawab how. Studi kasus versi Stake dianggap sesuai dengan alasan awal peneliti untuk melakukan penelitian berdasarkan kasus penerapan pagar api sebagai batas antara produk jurnalistik dan iklan, yaitu daya tarik langsung yang dimiliki oleh kasus. Peneliti menginginkan pemahaman lebih mendalam mengenai bagaimana sebenarnya FDN sebagai media gaya hidup digital menerapkan pagar api tersebut.

Metode studi kasus intrinsik karena pada penelitian ini sudah teridentifikasi kasus dengan

Penerapan Pagar Api pada Female Daily Network

(Cristine Manik, Henny Sri Mulyani dan Ika Merdekawati Kusmayadi) 
jelas, yaitu masalah penerapan pagar api pada konten yang diproduksi FDN. Kasus ini juga menjadi unik karena FDN merupakan pelopor pertumbuhan beauty platform di Indonesia. Uraian studi kasus yang ditumuskan Robert E. Stake berfokus pada pendekatan kualitatif dan bernuansa konstruktivis. Hal ini mejadi sesuai dan selaras dengan pertanyaan penelitian dalam penelitian ini. Dengan demikian, rumusan studi kasus Stake diputuskan untk digunakan demi mempertahankan koherensi dengan paradigma konstruktivis.

\section{HASIL DAN PEMBAHASAN}

Pelaku produksi dalam media gaya hidup ini baik website maupun YouTube tergabung dalam satu redaksi yang sama. Oleh karena itu kedua platform ini saling beririsan, baik dari segi pelaku produksi, maupun proses produksi.

Orang-orang yang terlibat dalam produksi artikel adalah tim editorial. Tim editorial bertanggung jawab merumuskan ide dan konsep produksi konten dalam rapat redaksi bersama tim video, menulis artikel editorial di website Femaledaily.com, mewawancarai brand manager produk kecantikan, melakukan liputan untuk brand launching dan membuat beritanya, bertanggung jawab atas konten yang diproduksi di social media. Tim editorial juga berperan ganda sebagai talent untuk YouTube FDN.

Tim editorial terdiri atas content lead/managing editor yang bertanggung jawab untuk mengatur key performance indicators (KPI) setiap anggota tim, membagi tugas sponsored post, senior content editor yang bertanggung jawab mengatur penjadwalan artikel, rapat dengan klien bersama tim sales, associate editor bertanggung jawab membuat konsep dan tema video dan menulis artikel.

Tim editorial masih bertanggung jawab untuk merumuskan ide dan konsep, termasuk untuk YouTube. Perumusan ide untuk video ini dibahas dalam satu rapat editorial bersama tim video. Selanjutnya, talent, merupakan gabungan tim editorial dan beberapa karyawan FDN. Talent merupakan orang-orang yang tampil di depan layar. Karena konten YouTube didominasi oleh video berbentuk ulasan, maka tugas talent adalah mengulas produk kecantikan seperti lipstick, penuci muka, foundation, dan sebagainya. Tim video, tim ini bertanggung jawab atas semua hal-hal teknis pada pembuatan video. Apabila editor merumuskan ide, tim video yang mengeksekusinya. Tim ini terdiri dari satu orang video produser, tiga orang video editor, dan videographer/photographer.

Proses produksi dapat dikelompokkan menjadi dua bagian besar, yaitu presales dan running campaign. Pada bagian pre sales, peneliti akan menjelaskan peran tim sales dan tahap negosiasi dengan sponsor sampai kesepakatan terjadi. Tim sales dikelompokkan dalam dua fungsi kerja, yaitu account executive (AE) dan campaign executive (CE). Tahap presales merupakan tanggung jawab dari AE dan CE. AE berperan penting untuk membuat klien tertarik untuk jadi mengiklan di platform milik FDN, sementara CE berperan sebagai jembatan antara tim editorial dan pengiklan saat kerja sama sudah deal.

Berikut tabel penawaran iklan yang disusun berdasarkan pengamatan peneliti:

Tabel 2 Jenis iklan di FDN

\begin{tabular}{|l|l|}
\hline \multicolumn{1}{|c|}{ Iklan Online } & \multicolumn{1}{c|}{ Iklan Offline } \\
\hline Website Banner & Meet and Greet \\
\hline Artikel & Beauty Workshop \\
\hline Instagram & FDN goes to campus \\
\hline Video on Youtube & Brand Launching \\
\hline
\end{tabular}

Sumber: Observasi Peneliti

Penerapan Pagar Api pada Female Daily Network

(Cristine Manik, Henny Sri Mulyani dan Ika Merdekawati Kusmayadi) 
182 | Kajian Jurnalisme

Volume 04 Nomor 02 Tahun 2021

DOI: $10.24198 / \mathrm{jkj} . \mathrm{v} 4 \mathrm{i} 2.27156$

Apabila klien setuju dengan penawaran yang diberikan AE, maka akan dilaksanakan proses selanjutnya, yaitu penandatanganan media order. Tugas AE selesai sampai media order ditandatangani.

Memasuki tahap running campaign, CE akan menanyakan kepada klien produk apa yang akan di highlight untuk diberitahu ke tim editorial. CE sebagai jembatan komunikasi akan bertugas sampai produk iklan ditayangkan. Jembatan komunikasi ini memiliki fungsi yang krusial agar tidak terjadi disinformasi antara klien dan tim produksi. Selanjutnya hal ini akan berhubungan dengan konsep iklan yang ditawarkan dengan produk iklan yang tayang, apakah sesuai kesepakatan atau tidak.

CE selalu mengirimkan draft produk sebelum dirilis ke platform FDN. Hal ini bertujuan memberi kesempatan kepada klien mereview dan memberi feedback. Bentuk yang dihasilkan adalah artikel advertorial dan video advertorial.

Female Daily Network meyakini semua ulasan yang diulas menghasilkan ulasan yang jujur, sehingga tidak perlu ada segmen yang membedakan editorial dan advertorial. Untuk memeriksa hasil pernyataan Female Daily Network, observasi dilakukan terhadap tayangan video advertorial dan artikel editorial yang diunggah di YouTube dan femaledaily.com selama bulan Mei hingga Juli 2019. Peneliti mengamati waktu upload dan penempatan segmen konten bersangkutan.

FDN membuat kebijakan untuk mengunggah video di YouTube enam kali dalam seminggu, kecuali hari Senin. Hal ini didasari laporan jumlah watch time oleh YouTube. Dari total 68 video yang diupload Selama Mei-Juli 2019, terdapat 16 video, atau sekitar 25\% dari seluruh video mengandung pesan komersil. Video yang mengandung pesan komersil tersebut tersebar di berbagai segmen regular. Tidak ada segmen khusus yang disediakan FDN untuk membedakan konten bersponsor dan editorial biasa.

Female Daily Network tidak memiliki penulis yang berasal dari tim sales, khusus untuk menulis artikel advertorial. Semua artikel diatas ditulis oleh tim redaksi. Pada dasarnya, FDN sudah memberikan tanda untuk menunjukkan 'editorial' yang mereka tulis bekerja sama dengan sponsor. Tiap artikel di website akan di-tag ke dalam beberapa kategori. Advertorial biasanya akan di-tag ke dalam kategori sponsored post. Semua advertorial yang ditulis oleh editor FDN membutuhkan approval dari pengiklan.

Mosco mendefinisikan studi ekonomi-politik sebagai studi mengenai kontrol dan usaha bertahan hidup di kehidupan sosial. Dalam konteks ini, Mosco menjelaskan kontrol dan usaha bertahan hidup sebagai bagian dari komunikasi sebuah perusahaan. Kontrol diartikan sebagai upaya sistem sosial mengorganisasi dirinya sendiri dalam menghadapi perubahan. Berdasarkan interpretasi tersebut, Mosco menyatakan kontrol sebagai sebuah proses politik karena ia membentuk hubungan dalam suatu komunitas dan usaha bertahan hidup merupakan proses ekonomi karena melibatkan proses produksi dan reproduksi (Mosco, 2009).

Berdasarkan definisi Mosco, Female Daily Network merupakan perusahaan yang terus melakukan kontrol atas produk yang diproduksinya. Serupa dengan media gaya hidup lain, Female Daily Netwrok memproduksi informasi mengenai gaya hidup dan dikemas dalam bentuk teks atau audio-visual (editorial). Di sinilah FDN melakukan kontrol atas editorial yang diproduksi oleh tim redaksi. Produk 'editorial' ini dimanfaatkan oleh FDN untuk menghasilkan profit sehingga FDN mampu melangsungkan hidup.

Media massa merupakan produsen budaya yang lebih berperan sebagai mesin pencari keuntungan (Murdock \& Golding, 1997). Bagi Chomsky, setiap keping informasi pada media massa telah disusupi kepentingan dan kekuatan politik dan bisnis (Subiakto \& Ida, 2012).

Untuk mengetahui bagaimana media massa mencari keuntungan, Mosco lebih lanjut

Penerapan Pagar Api pada Female Daily Network

(Cristine Manik, Henny Sri Mulyani dan Ika Merdekawati Kusmayadi) 
menjabarkan ada tiga aspek yang bekerja dalam sebuah sistem ekonomi politik, yaitu: komodifikasi, spasialisasi, dan strukturasi. Secara singkat komodifikasi merupakan proses menjadikan sebuah produk memiliki nilai jual. Mosco memandang komodifikasi dari tiga aspek, yaitu konten, khalayak, dan pekerja. Spasialisasi adalah proses mengatasi kendala ruang geografis dengan memanfaatkan teknologi komunikasi. Terakhir, Strukturasi. Strukrurasi merupakan proses menciptakan hubungan sosial, terutama yang diorganisasikan di sekitar kelas sosial, gender, dan ras (Mosco, 2009).

Komodifikasi konten dapat dimaknai sebagai proses transformasi pesan yang memiliki nilai guna, menjadi produk yang dapat dijual (Mosco, 2009). Female Daily Network melakukan komodifikasi pada produk jurnalistiknya dengan menambah nilai komersil di dalamnya. Teknik pengemasan pesan komersil yang disembunyikan di balik produk jurnalistik inilah yang kemudian ditawarkan kepada pengiklan. Dalam hal ini, hampir seluruh pengiklan di FDN merupakan brand-brand kosmetik dan perawatan kulit.

Komodifikasi konten yang dilakukan Female Daily Network yang ahirnya menciptakan advertorial. FDN memiliki dua platform untuk menyebarkan kontennya, website dan YouTube. Maka dari itu advertorial di FDN bisa berbentuk teks maupun audiovisual. Advertorial ini kemudian dimanfaatkan produsen sebagai agenda kapital. FDN merupakan media gaya hidup perempuan dengan konten yang mereka fokuskan pada informasi produk kecantikan. Topik editorial di media ini didominasi oleh ulasan (review) kosmetik dan perawatan kulit.

Proses komodifikasi konten memiliki peluang kemajuan yang besar seiring pertumbuhan internet. Mosco menyatakan internet memperdalam dan memperluas peluang perusahaan untuk mengukur, memantau, serta mengemas ulang konten komunikasi (Mosco, 2009). Sebagai sebuah media berbasis digital, Female Daily Network juga memanfaatkan keunggulan internet untuk melanggengkan proses komodifikasi mereka. Interaktifitas yang ditawarkan internet jugalah yang membuat media ini perlahan-lahan mengubah wajahnya dan mengubah konten yang diproduksi mereka.

Selanjutnya, peneliti akan membahas komodifikasi audiens (penonton). Mosco mendefinisikan komodifikasi audiens serupa dengan komodifikasi konten, namun dengan objek yang berbeda. Proses pemberian nilai jual ditujukan kepada khalayak dengan memperhatikan ukuran dan kualitas (kecenderungan khalayak untuk mengonsumsi).

Smythe (dalam Subiakto \& Ida, 2012) mengemukakan pandangannya bahwa penonton (audiens) merupakan komoditas yang dibeli pengiklan dalam ekonomi politik komunikasi. Symthe juga memandang penonton merupakan komoditas utama dari media. Apa yang dijual oleh media komersial kepada klien mereka adalah kurang lebih jaminan dari jumlah konsumen potensial yang banyak tergantung pada profil yang sesuai dengan pasar.

Perspektifkomodifikasi audiens ini lebihjauh diterapkan dalam iklan online dan khususnya pada mesin pencari (search engine) sebagai kendaraan utama bagi periklanan (McQuail, 2010). Symthe menyatakan bahwa kunci ekonomi internet terletak pada komodifikasi pengguna yang memiliki akses gratis yang menyampaikan target bagi pengiklan dan agen publikasi, seperti menyediakan konten kepada penyedia jaringan dan pemilik situs gratis (Subiakto \& Ida, 2012).

Komodifikasi khalayak di Female Daily Network berkaitan dengan jumlah klik, views, dan member yang didapatkan mereka. Tiga faktor inilah yang menjadi jualan utama pengiklan. Pada kolom about us di laman femaledaily.com dipaparkan bahwa media ini memiliki lebih dari 300 ribu follower media sosial, 7,5 juta kunjungan website, dan sekitar 2 juta member. Jumlah kunjungan, followers dan subscribers ini akhirnya menjadi barang yang diperjualbelikan FDN dengan pengiklan. Ketika suatu konten disebar kepada khalayak, dan konten itu dikonsumsi oleh khalayak, maka jumlah konsumsi itulah yang diinginkan oleh pengiklan. 
184 | Kajian Jurnalisme

Volume 04 Nomor 02 Tahun 2021

DOI: $10.24198 / \mathrm{jkj} . \mathrm{v} 4 \mathrm{i} 2.27156$

Tujuan pengiklan adalah untuk menyampaikan pesan tertentu dan mengharapkan dampak dari penyampaian pesan tersebut (Widyatama, 2007). Hal ini jugalah yang dibeli dari pengiklan di Female Daily Netwrok. Putri Mahardika, Account Executive FDN menjelaskan biasanya tujuan klien mengiklan adalah untuk memberi awareness ke user, member, dan followers Female Daily tentang brand mereka, dan memperkenalkan brand mereka. Penetapan harga iklan di FDN didasari pada persentase audiensnya. Semakin tinggi jumlah followers atau subscriber, semakin tinggi jumlah konsumsi khalayak terhadap konten yang diproduksi FDN.

Menurut Detta Rahmawan, dosen dan peneliti kajian media, menyatakan komodifikasi khalayak yang dilakukan media wajar adanya. Yang menjadi pertanyaan adalah apakah komodifikasi khalayak ini efektif.

"Efektivitas dalam periklanan di Indonesia ini banyak yang harus dipertanyakan juga sih. Bahkan dunia content creator dan influencer di Indonesia sangat hiperbolis. Dari tahun 2016 saya nanya ke teman-teman saya di industry, kok lo mau sih ngasih orang yang berapa banyak followersnya atau subscribernya dikasih 10 juta misalnya. Itu cuma dikit loh yang bisa jelasin." (Rahmawan, Wawancara. 1 Agustus 2019)

Lebih lanjut Detta menyatakan belum pernah ada research yang menunjukkan banyak followers atau subscribers berbanding lurus dengan peningkatan konsumsi sebuah brand. Hal yang paling dibutuhkan dalam dunia periklanan digital bukan soal menjadikan khalayak memiliki nilai jual, lebih jauh dari itu, dalam iklan harus ada disclosure (pemberitahuan) dari pengiklan dan awareness (kesadaran) khalayak.

Mosco menjelaskan komodifikasi pekerja berkaitan dengan pengukuran waktu dan tenaga paling efisien yang dibutuhakan dalam proses produksi (Mosco, 2009). Tenaga kerja terbentuk dari kesatuan orang dengan kemampuan kemampuan untuk merencanakan, merancang, dan melaksanakan pekerjaan. Komodifikasi pekerja dilakukan kapitalis untuk menekan biaya produksi dan menngkatkan pendapatan. Hal yang dapat dilakukan untuk menekan biaya produksi dapat dilakukan dengan dua cara. Pertama, dengan mengganti pekerja dengan mesin. Kedua adalah dengan menambah beban kerja tenaga pekerjanya. Dari hasil observasi peneliti, hal kedua ini terjadi di Female Daily Network.

Tim produksi juga hanya terdiri dari Sembilan orang. Satu orang video produser, tiga orang video editor, dan tiga orang video grapher yang merangkap menjadi fotographer. Sembilan orang inilah yang bertugas menghasilkan enam video dalam satu minggu. Begitu pula dengan semua talent video YouTube, yang merupakan karyawan FDN.

Penekanan biaya produksi dengan menambah beban pekerja di FDN bisa dilihat dari pernyataan Putri Rinda Haifa, Video Produser Female Daily network, mengamini bahwa FDN tidak pernah merekrut karyawan baru untuk dijadikan talent.

Peneliti melihat ketentuan yang ditetapkan FDN ini malah dimaklumi oleh karyawannya. Komodifikasi pekerja yang dilakukan FDN malah dianggap menjadi sebuah fleksibilitas untuk dapat melakukan pendekatan emosional dan personal dengan audiens.

"Orang jadi lebih familiar gitu sama orang-orang ini (talent) mungkin juga yang nonton lebih merasa conect ke personal-personal di video. Misalnya editor kita, Arinda. Arinda muncul di video tapi kelihatan juga gitu dia sebagai editor. Orang bisa baca tulisannya jadi kayak ngerasa kenal sama orang di video. Jadi kayak benar benar penonton tahu personalnya." (Haifa, Wawancara. 26 Juni 2019)

Susunan redaksi yang ideal adalah di mana setiap detail produksinya ditangani oleh satu orang atau satu tim khusus. Hal inilah yang tidak terlihat pada FDN. Tim editorial di media ini mengerjakan beban kerja yang sangat banyak. Selain menjadi talent, tim editorial memiliki peran lain menyangkut urusan periklanan. Dalam perusahaan ini, jajaran redaksi (tim editorial) 
juga mengurusi produksi iklan. Tim editorial memiliki tanggung jawab untuk menulis artikel advertorial. Padahal, hal ini haram hukumnya dalam dunia jurnalisme.

Spasialisasi dalam ekonomi politik Mosco mengacu pada konsentrasi media dan konglomerasi media yang dapat dipahami dengan konsep horizontal integration dan vertical integration (Mosco, 2009). Horizontal integration, berbicara mengenai ekspansi horizontal di mana satu grup media membeli media baru dalam jaringannya atau ketika media global membuka satu jaringan waralaba baru di suatu negara. Vertical integration berbicara mengenai kontrol perusahaan terhadap proses produksi, terutama melalui kebijakan bisnis. Spasialisasi dilakukan untuk memperluas jangkauan media kepada khalayak.

Istilah spasialisasi diperkenalkan oleh Henri Lefebvre untuk menunjukkan proses mengatasi kendala ruang dan waktu dalam kehidupan social (Mosco, 2009). Karl Marx mengungkap pandangannya bahwa spasialisasi mengacu pada kecenderungan kapitalisme untuk memusnahkan ruang dengan waktu.

FDN adalah perusahaan yang didirikan pada tahun 2005. Pada awalnya media ini berangkat dari blog pribadi dan membahas semua tentang perempuan. Tahun 2013 media ini berekspansi ke bidang lifestyle perempuan dan fokus pada ulasan produk kecantikan. Pasar yang dibidik adalah konsumen perempuan berusia 19-35 tahun yang mempunyai ketertarikan pada kecantikan kulit. Platform yang digunakan media ini untuk menyampaikan produk jualan media ini kepada khalayak adalah media digital.

Media digital sebagai media baru memiliki beberapa karakteristik untuk melanggengkan spasialisasi di FDN. Media baru membawa perubahan dalam komunikasi massa, yaitu ruang lingkup yang sangat luas dan lebih personal (Holmes, 2009). Media baru akan selalu memanfaatkan keunggulan dari digitalisasi, kemamupuan untuk memanipulasi dan melalui jarigan yang padat serta kompresibel dan interaktif. Ada beberapa kata kunci bila kita membahas wacana media baru, yaitu: digital, interaktif, hipertekstual, virtual, dan dapat disimulasikan (Lister, Dovey, Giddings, Kelly, \& Grant, 2009).

Keunggulan media baru inilah yang dimanfaatkan Female Daily Network untuk mengatasi batas ruang dan waktu. Kelebihan lain yang dimanfaatkan FDN adalah hypertext yang menjadi karakter media baru atau media digital. Hypertext adalah text yang berhubungan dengan dokumen lain atau teks yang nge-link ke informasi lain. Pada link dalam dokumen hypertext apabila di klik, maka dapat dengan cepat menuju/ melompat ke konten yang berbeda. FDN selalu mencantumkan link ke website femaledaily.com apabila satu video relevan dengan editorial yang mereka tulis. Link ini selalu ada di kolom deskripsi YouTube Female Daily Network.

Perkembangan teknologi komunikasi dan informasi memperluas jangkauan lokasi yang dapat menghubungkan orang dengan kekayaan, karena bisa memiliki akses langsung ke teknologi dan orang-orang yang memiliki kekuasaan (Mosco, 2009). Hal inilah yang sedang terjadi pada perusahaan ini, di mana pemilik modal menggunakan kelebihan digitalisasi pada media baru sebagai kedok untuk meraup profit yang lebih besar. Hal ini berkaitan dengan akumulasi kapital yang akan didapatkan pemiliki modal.

Strukturasi merupakan proses menciptaan makna secara struktural. Melalui perspektif ini, komunikasi dipandang sebagai peroses pembentukan makna sosial yang menciptakan relasi. Ekonomi politik dimulai dari pertemuan ekonomi dengan isu-isu ekonomi yang diangkat dalam komodifikasi, berlanjut ke isu spasial yang menghubungkan ekonomi politik dengan geografi, lalu dilanjut dengan hubungan ekonomi politik dengan masalah sosial (Mosco, 2009). Hasil akhir dari strukturasi adalah serangkaian hubungan sosial dan proses kekuasaan diorganisasikan di antara kelas, gender, ras dan gerakan sosial yang masing-masing berhubungan satu sama 
186 | Kajian Jurnalisme

Volume 04 Nomor 02 Tahun 2021

DOI: $10.24198 / \mathrm{jkj} . \mathrm{v} 4 \mathrm{i} 2.27156$

lain.

Dalam penelitian ini, strukturasi berawal dari usaha pembentukan makna yang dilakukan Female Daily Network dan pengiklan mengenai identitas perempuan modern, mandiri, dan trendi. Pada websitenya, Female Daily Network bercerita bahwa Female Daily Network merupakan wadah yang tepat bagi para perempuan untuk berinteraksi, sehingga dapat saling menginspirasi dan berbagi informasi.

FDN menekankan pembentukan identias perempuan yang modern, mandiri, dan trendi dengan mempromosikan krunya yang diklaim solid, multifungsi, cerdas, dan stylish, serta kepribadian founders-nya yang berpengalaman di media digital dan terampil memahami kebutuhan wanita. Klaim bahwa FDN memiliki kemampuan untuk menentukan tren sebelum terjadi, menguatkan branding bahwa FDN merupakan wadah yang tepat untuk perempuan modern, mandiri, dan trendi tadi mencari informasi yang dibutuhkannya. Pembentukan citra ini berkaitan dengan keinginan pemilik modal untuk bisa mengambil keuntungan atas preferensinya terhadap komodifikasi produk media.

Interaksi dan struktur adalah dua hal yang berhubungan dengan erat. Kita bertindak secara sengaja untuk mencapai tujuan kita, tetapi pada saat yang sama tindakan kita akan menghasilkan apa yang disebut "konsekuensi tidak disengaja" (unintended consewuences) yang menghasilkan berbagai truktur dan mempengaruhi tindakan kita di masa depan (Morissan, 2014). Dalam konteks strukturasi di Female Daily Network ini, citra yang berusaha dibangun FDN ini membentuk 'unintened consequence' yaitu hegemoni FDN atas khalayaknya dan hegemoni pengiklan atas Female Daily Netwrok. Hegemoni inilah yang akan membawa keuntungan bagi FDN dan pengiklan.

Morissan (2014) mendefinisikan sebagai pengaruh, kekuasaan, atau dominasi kelompok sosial tertentu atas suatu kelompok sosial lainnya yang biasa lebih lemah. Menurut Antonio Gramsci, hegemoni melahirkan kesadaran yang salah di mana individu menjadi tidak menyadari adanya dominasi dalam hidup mereka. Gramsci menyatakan sistem sosial yang mereka dukung justru mengeksploitasi diri mereka sendiri (Jones, 2007).

Khalayak Female Daily Network tidak menyadari bahwa FDN telah mendominasi hidup mereka dengan menjadi trendsetter atas tren kecantikan. Konsumen juga tidak menyadari bahwa mereka telah dieksploitasi untuk dijadikan komoditas kepada pengiklan dan dipengaruhi pesan-pesan komersil titipan pengiklan dalam produk editorial FDN.

Hegemoni juga terjadi antara relasi FDN dengan pengiklan. Tim editorial di Female Daily Network menganggap lumrah untuk membuat satu editorial disesuaikan dengan keinginan pengiklan. Tim editorial dan tim produksi video menganggap mengirimkan draft edvertorial dan menunggu feedback maupun approval pengiklan merupakan bagian dari sistem kerja produksi di FDN, tanpa menyadari letak dominasi pengiklan di dalamnya.

Keadaan di media ini sejalan dengan pandangan Gramsci yang memahami kekuasaan sebagai sesuatu hal yang secara terus menerus dihidupkan hingga menjadi suatu kewajaran (common sense) (Jones, 2007). Gramsci menilai hegemoni sebagai suatu proses tawarmenawar, sebuah negosiasi yang simultan untuk menentukan maknan yang berkembang (titik keseimbangan) dalam sebuah kebudayaan yang diamini dengan sukarela. Proses tersebut dapat terjadi dalam beberapa aspek, salah satunya dengan kesepakatan bisnis antara pengiklan dan media massa.

Pada akhirnya kapitalisasi yang ada dalam media ini telah melahirkan jurnalisme yang dikendalikan oleh pasar (market-driven journalism). Market-driven journalism didefinisikan sebagai berita yang mengikuti logika pasar untuk menciptakan lingkungan yang mendukung usaha komersialisasi. Market-driven journalism memandang audiens sebagai costumer alih-aluh

Penerapan Pagar Api pada Female Daily Network

(Cristine Manik, Henny Sri Mulyani dan Ika Merdekawati Kusmayadi) 
memandang sebagai citizen. Hal tersebutlah yang dipraktikkan oleh Female Daily Network, di mana konten-konten yang diproduksinya didasarkan oleh kebutuhan audiens, untuk mendapat income yang lebih besar.

Salah satu hal paling nyata yang bisa diamati adalah perubahan konten di FDN sepanjang tahun 2005 hingga 2019. Di awal media ini berdiri media ini memproduksi editorial yang membahas semua ranah lifestyle wanita, baik fashion, hijab, maupun make up. Tahun 2017 pihak redaksi menetapkan kebijakan pada media ini untuk mengubah produksi kontennya mejadi editorial berbentuk ulasan dengan fokus kosmetik.

Menurut McManus, ciri lain dari market-driven journalism adalah pasar menjadi kekuatan dalama peliputan, pemilihan, dan pelaporan berita. Rutinitas ini pula yang terjadi pada FDN, di mana mereka membatasi biaya liputan dan sedapat mungkin mempuat laporan berita dengan mengeluarkan biaya minimal, tetapi mampu menjangkau audiens yang luas.

Liputan di media ini hanya dilakukan apabila ada undangan dari brand. Produksi konten kebanyakan dilaksanakan di studio, hingga menghasilkan informasi yang lmenekankan pada dimensi hiburan. Pada akhirnya, produk jurnalistik yang diproduksi hanya menyentuh kebutuhan personal masyarakat (Dharker, Herman, \& McChesney, 1998).

Female Daily Network memanfaatkan karakteristik yang ada pada media baru untuk meraih pasar yang lebih luas lagi. Kemunculan media baru telah merubah karakter media massa. Media baru memungkinkan terjadinya percakapan antar-banyak pihak, memungkinkan penerimaan secara simultan dan menyediakan kontak global secara instan (McQuail, 2010).

McQuail (2010) menyebutkan pengguna membutuhkan interaktivitas, kontak personal dengan orang lain, kekayaan media yang dapat menjembatani kerangka referensi berbeda, kendali atas konten dan penggunaan, hiburan, privasi, dan personalisasi di mana suatu konten dapat dinikmati secara personal.

Dewan Pers (2012) dalam Pedoman Pemberitaan Media Siber mengartikan media siber (daring) sebagai segala bentuk media yang menggunakan wahana internet dan melaksanakan kegiatan jurnalistik, serta memenuhi persyaratan Undang-Undang Pers dan Standar Perusahaan Pers yang ditetapkan Dewan Pers (Romli, 2012). Berdasarkan definisi ini, FDN merupakan salah satu media daring.

Membahas tentang perkembangan media gaya hidup tentu tak jauh dari budaya populer yang berkembang. Budaya populer merupakan produk budaya yang diproduksi secara massal, ada dimana-mana, dan tidak memerlukan usaha untuk menemukannya (Subiakto \& Ida, 2012). Salah satu manifestasi dari budaya populer itu adalah gaya hidup. Budaya ini dipraktikkan, disebarkan, dan dimediakan dalam kehidupan sehari-hari dalam kehidupan masyarakat Indonesia (Ibrahim, 2007). Serbuan gaya hidup ini didistribusikan melalui iklan dan televisi hingga sampai ke ruang-ruang paling pribadi khalayaknya.

Dalam hal inilah FDN bekerja dalam praktik industri budaya. FDN menempatkan dirinya sebagai patron yang membentuk narasi gaya hidup dalam membentuk identitas pembacanya melalui segmentasi khalayaknya. Dalam praktiknya, FDN menyebarkan narasi-narasi budaya populer tersebut melalui produk jurnalistik yang dihasilkannya. Produk jurnalistik merupakan konten yang terdapat pada media massa, secara umum digolongkan menjadi dua bagian, news dan views (Sumadiria, 2014).

Media memiliki dua wajah, sebagai institusi sosial dan sebagai institusi bisnis. Sebagai institusi sosial, media bertanggung jawab untuk memberikan informasi yang benar terhadap masyarakat. Sebagai institusi bisnis, media massa juga media daring membutuhkan pemasukan untuk memenuhi kebutuhan operasionalnya agar terus bertahan hidup, salah satu caranya adalah menerima iklan. Hal inilah yang dilakukan oleh Female Daily Network. Permasalahannya, 
188 | Kajian Jurnalisme

Volume 04 Nomor 02 Tahun 2021

DOI: $10.24198 / \mathrm{jkj} . \mathrm{v} 4 \mathrm{i} 2.27156$

terjadi bias batasan antara produk jurnalistik dan iklan di media ini. Dalam dunia jurnalisme, batasan ini dikenal dengan istilah 'pagar api'. Pagar api ada untuk memisahkan urusan advertisement dan editorial (Harsono, 2010).

Dalam buku Jurnalisme Kontemporer dijelaskan bahwa jurnalisme gaya hidup mulai berkembang tahun 1900-an. Koran-koran metropolis mulai memuat berbagai rubrik mengenai fashion, food, household, hints, society, and advice. Rubrik ini diciptakan untuk berburu pemasukan uang yang lumayan dan bermuatan iklan dengan harga tinggi. Tujuan ini ternyata berhasil. Mulai tahun 1940-an, berita-berita gaya hidup mulai digarap secara profesional. Jemputan iklan menghambur ke dalam pemberitaan gaya hidup. Iklan menyelusup ke dalam halaman gaya hidup melalui pemberitaan makanan, fesyen, dan perabot rumah. Dari sana, berita gaya hidup mengikuti dinamika, perkembangan, dan nuansa hidup masyarakat. Juga, peluang untuk tetap menghasilkan profit (Santana, 2017).

Saat ini kita mengenal istilah advertorial gabungan dua kata: advertisement dan editorial (Harsono, 2010). Advertorial merupakan bentuk periklanan yang disajikan dengan gaya bahasa jurnalistik. Dalam media digital, advertorial juga dikenal sebagai content creation. Produk advertorial yang dimanfaatkan oleh Female Daily Network untuk menghasilkan profit.

Peraturan mengenai penerapan pagar api sebenarnya sudah ada regulasinya. Regulasi tersebut diatur dalam Pedoman Pemberitaan Media Siber yang dikeluarkan oleh Dewan Pers tepatnya nomor enam mengenai pemuatan iklan. Poin yang digarisbawahi pada aturan tersebut adalah: (1) Media siber wajib membedakan dengan tegas antara produk berita dan iklan; (2) Setiap berita/artikel/isi yang merupakan iklan dan atau berbayar wajib mencantumkan keterangan "advertorial", "iklan", "ads", "sponsored", atau kata lain yang menjelaskan bahwa berita/artikel/isi tersebut adalah iklan (Dewan Pers, 2012).

Pada dasarnya, Female Daily Network telah mencoba melaksanakan pedoman ini dengan membuat tag sponsored post di setiap artikel dan deskripsi 'thankyou (brand) for supporting our video' pada description box di YouTube FDN. Masalahnya, meskipun media ini menyertakan tag tersebut, konten iklan diletakkan di kanal atau segmen yang sama dengan editorial untuk menyamarkan keberadaan iklan. Pada website femaledaily.com, seluruh artikel advertorial dimasukkan dalam kanal bernama 'editorial'. Hal ini melanggar aturan yang tersurat di Etika Pariwara Indonesia.

Aturan yang dilanggar itu mengatur tentang mengenai iklan pada poin 4.9 tentang penajaan (sponsorship). Berikut isi aturan tersebut: (1) Iklan yang tampil pada ruang atau waktu penajaan tidak boleh dirancang sedemikian rupa, sehingga sama atau amat menyerupai isi atau program yang ditajanya. Sedangkan yang terjadi di Female Daily Network adalah kebalikan dari pedoman ini. FDN berusaha menyampaikan pesan titipan sponsor sehalus mungkin dengan tidak membedakan style pembuatan editorial dan advertorial. Regiana Mantikan, Video editor Female Daily Network menjelaskan dalam proses editing video, Female Daily Network tidak pernah membedakan yang mana video sponsor atau bukan sponsor. Putri Rinda Haifa, Video Produser Female Daily Network menyatakan bahwa Female Daily Network memiliki style yang sama baik untuk video sponsor maupun bukan sponsor, stylenya tidak dibedakan. (2) Identitas dari penaja sesuatu ruang atau waktu media harus ditampilkan secara jelas. Ketentuan ini sudah dijalankan oleh Female Daily Network dengan menyertakan tag sponsored post. (3) Tajuk (editorial) sesuatu media tidak boleh ditaja (Dewan Periklanan Indonesia, 2020). Poin ini jelas sekali sudah dilanggar oleh Female Daily Network dengan memasukkan artikel sponsor di kanal editorial di website femaledaily.com.

Detta Rahmawan menyatakan tidak ada yang salah dari menerima dan memasang iklan, yang menjadi masalah adalah aturan batas mengiklan yang selalu diabaikan.

Penerapan Pagar Api pada Female Daily Network

(Cristine Manik, Henny Sri Mulyani dan Ika Merdekawati Kusmayadi) 
"Batas antara content creation dan karya jurnalistik itu harus ada. Kadang saya berpikir mengapa para content creator itu tidak disclouse, mungkin karena mereka punya ketakutan irrasional bahwa mereka dianggap tidak authentic. Sebetulnya tidak pernah juga ada data yang menunjukkan ketidakautentikan itu akan berpengaruh negative terhadap pembelian. Kalau saya jadi brand, terus permintaan saya jangan sampai kelihatan iklan, itu brandnya juga bego. Brengsek. Tapi kenapa dia jadi bego, brengsek, mungkin dalam kacamatanya dia semua orang yang iklan negatif. Negatif terhadap brand awareness, conversion pembelian, padahal gak pernah ada data mentahnya." (Rahmawan, Wawancara. 1 Agustus 2019)

Harsono (2010) menyatakan bahwa advertorial termasuk dalam ranah bisnis, maka harus ada batas antara advertorial dan editorial (pagar api) yang sudah seharusnya diproduksi oleh tim marketing/advertising. Redaktur dan wartawan tidak usah ikut campur urusan iklan, dan bagian iklan tidak boleh direpoti keinginan redaksi.

Editorial dan advertorial di media ini dikerjakan oleh tim yang sama, di dapur redaksi. Advertorial dan editorial diperlakukan sama, sama-sama dibahas dalam rapat redaksi dan sama-sama diproduksi oleh tim editorial.

Dampaknya adalah redaksi harus berkomunikasi dengan pengiklan untuk menghasilkan advertorial yang sesuai. Pada alur produksi advertorial di Female Daily Netwrok, draft artikel atau video akan dikirimkan oleh tim editorial atau tim video kepada klien. Draft tersebut akan diperiksa oleh pengiklan. Butuh persetujuan dari pengiklan terlebih dahulu agar konten dapat disebar.

Elemen keempat dari sembilan elemen jurnalisme berbunyi "Its practitioners must maintain an independence from those they cover" (Kovach \& Rosenstiel, 2007). Praktisi jurnalisme harus menjaga independensinya dari sumber yang diliputnya. Bila dikaji lebih lanjut, aturan mengenai independensi ini dijelaskan pada pasal 1 Kode Etik Jurnalistik (KEJ) yang berbunyi "Wartawan Indonesia bersikap independen, menghasilkan berita yang akurat, berimbang, dan tidak beritikad buruk". Independen berarti memberitakan peristiwa atau fakta sesuai dengan suara hati nurani tanpa campur tangan, paksaan, dan intervensi dari pihak lain termasuk pemilik perusahaan pers. Akurat berarti dipercaya benar sesuai keadaan objektif ketika peristiwa terjadi. Berimbang berarti semua pihak mendapat kesempatan setara. Tidak beritikad buruk berarti tidak ada niat secara sengaja dan semata-mata untuk menimbulkan kerugian pihak lain.

Berdasarkan penafsiran tersebut, semua editor di Female Daily Network tidak dapat memproduksi artikel yang independen. Tim editorial (redaksi) menganggap menulis advertorial merupakan bagian dari kerja mereka, sehingga tidak ada yang salah dalam hal tersebut. Hal itu yang membuat dapur kerja redaksi dan marketing pada dasarnya tidak boleh disatukan.

\section{SIMPULAN}

Female Daily Network memproduksi advertorial atau dalam media baru disebut content creation untuk memperoleh pendapatan agar tetap bertahan hidup. Advertorial yang diproduksi berupa artikel yang diunggah di website femaledaily.com dan video yang di-upload di Channel YouTube Female Daily Network. Tahapan produksi advertorial dimulai dari proses penjualan yang merupakan tanggung jawab tim sales dan proses running campaign yang merupakan tanggung jawab tim redaksi dan tim video. Dalam alur produksi advertorial, Female Daily Network memperbolehkan sponsor melakukan intervensi ke pihak internal melalui jembatan komunikasi lewat tim sales. Aktivitas jurnalisme pada Female Daily Network dipengaruhi oleh pasar (market-driven journalism), sehingga kebijakan yang diterapkan semata-mata untuk mendapatkan keuntungan bagi FDN dan kliennya. FDN tidak memiliki kebijakan yang tegas 
190 | Kajian Jurnalisme

Volume 04 Nomor 02 Tahun 2021

DOI: $10.24198 / \mathrm{jkj} . \mathrm{v} 4 \mathrm{i} 2.27156$

untuk membatasi sejauh mana media ini dapat memfasilitasi iklan. Dipandang dari sisi ekonomi politik Mosco, komunikasi antara Female Daily Network dan klien dilakukan agar kedua belah pihak saling diuntungkan dengan memaksimalkan komodifikasi, spasialisasi, dan strukturasi.

Dalam praktiknya, Female Daily Netwrok sudah berusaha menerapkan pagar api agar karya yang diproduksi sesuai dengan elemen, etika jurnalistik, dan etika pariwara dengan memberi tanda 'sponsored post' di konten bersponsor. Namun penerapan pagar api masih belum maksimal mengingat advertorial di Female Daily Netwrok punya dapur produksi yang sama dengan editorial, penempatan advertorial di kanal dan segmen yang tidak tepat, dan intervensi pengiklan yang dominan.

\section{DAFTAR PUSTAKA}

Alfarabi. (2010). Kajian komunikasi kritis terhadap ekonomi politik media. Jurnal IDEA FISIPOL UMB, 4(17), 1-4. Diakses dari http://repository.unib.ac.id/571/

Baran, S. J. (2011). Pengantar komunikasi massa: Literasi media dan budaya. Jakarta: Salemba Humanika.

Basen, I. (2012). Breaking down the wall. Diakses pada June 30, 2020, dari https://ethics. journalism.wisc.edu/2012/12/19/breaking-down-the-wall/

Dewan Periklanan Indonesia. (2020). Etika pariwara Indonesia amandemen 2020. Jakarta.

Dewan Pers. (2012). Pedoman pemberitaan media siber. Jakarta. Diakses dari https://dewanpers. or.id/assets/documents/pedoman/1907090253_-2012_PEDOMAN_PEMBERITAAN_ MEDIA_SIBER.pdf

Dharker, A., Herman, E. S., \& McChesney, R. W.(1998). The global media: The new missionaries of corporate capitalism. Foreign Policy, (111), 132-135. https://doi.org/10.2307/1149383

Female Daily Network. (2018). Female Daily Network's history.

Harsono, A. (2010). Agama saya adalah jurnalisme. Yogyakarta: Kanisius.

Holmes, D. (2009). New media theory. In Encyclopedia of Communication Theory. (p. 684). SAGE Publications Ltd.

Ibrahim, I. S. (2007). Budaya populer sebagai komunikasi. Yogyakarta: Jalasutra.

Jones, S. (2007). Routledge critical thinkers: Antonio gramsci. (R. Eaglestone, Ed.). London: Routledge. https://doi.org/10.4324/9780203625521

Kovach, B., \& Rosenstiel, T. (2007). Elements of journalism. New York: Crown Publishers.

Lamalo, A. A. (2013). Penerapan prinsip firewall di Harian Manado Post (on the application of firewall principle in Manado Post Daily). Acta Diurna Komunikasi, 2(4), 19. Diakses dari https://ejournal.unsrat.ac.id/index.php/actadiurnakomunikasi/article/view/2875/2426

Lister, M., Dovey, J., Giddings, S., Kelly, K., \& Grant, I. (2009). New media: a critical introduction (2nd ed.). London: Routledge. Diakses dari http://www.philol.msu. $\mathrm{ru} / \sim$ discours/images/stories/speckurs/New_media.pdf

McQuail, D. (2010). McQuail's mass communication theory. London: SAGE Publications Ltd. Moleong, L. J. (2017). Metodologi penelitian kualitatif. Bandung: PT. Raja Grafindo Persada.

Morissan. (2014). Teori komunikasi individu hingga massa. Jakarta: Kencana.

Mosco, V. (2009). The political economy of communication. London: SAGE Publications Ltd. https://doi.org/10.4135/9781446279946

Murdock, G., \& Golding, P. (1997). The political economy of the media. UK: Edward Elgar Publishing.

Nabila, M. (2017). PwC: Media internet diprediksi kuasai 20\% porsi iklan Indonesia tahun 2021. Diakses pada June 30, 2020, dari https://www.pwc.com/id/en/media-centre/ pwc-in-news/2017/indonesian/pwc--media-internet-diprediksi-kuasai-20--porsi-iklan-

Penerapan Pagar Api pada Female Daily Network

(Cristine Manik, Henny Sri Mulyani dan Ika Merdekawati Kusmayadi) 
DOI: $10.24198 / \mathrm{jkj} . \mathrm{v} 4 \mathrm{i} 2.27156$

indonesia-.html

Nasrullah, J. (2020). Breaking down "Firewall" among public relations and journalism. Jurnal Interaksi : Jurnal Ilmu Komunikasi, 4(1), 86-97. https://doi.org/10.30596/interaksi. v4i1.3957

Neumann, W. L. (2003). Social research methods: Qualitative and quantitative approach. Boston: Allyn and Bacon.

Nielsen. (2016). Pertumbuhan belanja iklan menunjukkan arah positif. Diakses pada June 4, 2020, dari https://www.nielsen.com/id/en/press-releases/2016/pertumbuhan-belanjaiklan-menunjukkan-arah-positif/

Ochell. (2019). Haircare routine untuk rambut rusak \& dicat ala ochell. Diakses dari https:// editorial.femaledaily.com/blog/2019/07/23/haircare-routine-untuk-rambut-rusak-dicatala-ochell/haircare-routine-untuk-rambut-rusak-dicat-ala-ochell/

Romli, A. S. (2012). Jurnalistik online: Panduan praktis mengelola media online. Bandung: Nuansa Cendekia.

Santana, S. (2017). Jurnalistik kontemporer (2nd ed.). Jakarta: Yayasan Pustaka Obor Indonesia.

Stake, R. (2005). Case Studies, dalam Denzin dan Lincoln (ed) Handbook of Qualitatives Research. London: SAGE Publications Ltd.

Subiakto, H., \& Ida, R. (2012). Komunikasi politk, media, dan demokrasi. Bandung: Kencana.

Sumadiria, H. (2014). Bahasa jurnalistik: Panduan praktis penulis dan jurnalis. Bandung: Simbiosa Rekatama Media.

Widyatama, R. (2007). Pengantar periklanan. Yogyakarta: Pustaka Book Publisher.

Yin, R. K. (2014). Studi kasus desain dan metode. Jakarta: Rajawali Press. 